\title{
LABELING THE
}

MENTALLY RETARDED 



\section{Labeling}

the

Mentally

Retarded

Clinical and Social System

Perspectives on

Mental Retardation

by

JANE R. MERCER

University of California Press

Berkeley, Los Angeles, London 
University of California Press

Berkeley and Los Angeles, California

University of California Press, Ltd.

London, England

Copyright $\odot 1973$, by

The Regents

of the University of California

ISBN: 0-520-02183-5 (cloth)

ISBN: 0-520-02428-1 (paperback)

Library of Congress

Catalog Card Number: 70-182795

Printed in the United States of America 


\section{TO}

Harvey F. Dingman

Teacher, Colleague, and Friend 
